\title{
Zintegrowane projektowanie zrównoważone
}

\section{Integrated sustainable design}

\section{Streszczenie}

XXI wiek przyniósł w dziedzinie projektowania rewolucję większą niż miała miejsce przy zamianie deski kreślarskiej na oprogramowanie komputerowe CAD. Mamy do czynienia z niezwykle dynamicznym rozwojem technologii oraz koniecznościa stosowania się do wy nogow zwiazany z zrojektowaniem zrownozazn. Projektowanie zrownowazone wymaga scisłej

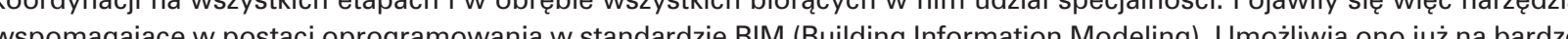
wczesch etapach opracowywania koncepcii budynku wprowadzenie szeregu istotnych parametrów i wykonanie wstep nych analiz stużacych zrównoważonemu projektowaniu. Wyniki tych analiz pozwalaja na skorygowanie przyjetych załoie projektowych i ich optymalizacje Nauczanie projektowania zrównoważonego w oparciu o te technologie jest dziś niezwykle pomocne dla architektów i inżynierów, a w przyszłości może sie stać nieodzowne. Dlatego edukacja w tym zakresie oraz integracja projektowania urbanistyczno-architektonicznego oraz budowlanego wydaje się być konieczna już od pierwszych lat studiów na wydziałach architektury.

Abstract

The $21^{\text {st }}$ century brought about a greater evolution in the field of designing than the one when the drawing board was replaced with the CAD software. We are dealing now with extremely dynamic development of technology and with the need to comply with requirements relating to sustainable design. Sustainable design requires strict coordination at all stages and within the scope of all specialties it concerns. Therefore, supporting tools have emerged - software in the BIM standard Building information Modelling). It enables to introduce a number of essential parameters and to perform preliminary analyses relating to sustainable design already at very early stages of the process of developing the concept of a building. The wests of with the support of these technologies is extremely helpful for architects and engineers today, and it can become indispensdesign seems to be necessary starting from the first years of study at faculties of architecture.

\section{Keywords: integrated sustainable design, BIM}

\section{. WPROWADZENIE}

Składową idei zrównoważonego rozwoju jest zrównoważone projektowanie opierające się na zasadach Green Architecture'. Przed projektami architektonicznymi wykonywanymi według tej idei stawia sie wymóg, aby spełniając terániejsze potrzeby ludzi nie powodowały jednocześnie negatywnych skutków środowiskowych, ekonomicznych i społecznych dla przyszłych pokoleń2. W praktyce oznacza to, że decyzje podejmowane w ramach „zrównoważonego projektowania" muszą być wynikiem wielokryterialnej analizy wpływu budynku na czlowieka oraz srodowisko, na etapie jego wznoszenia ksploatacji oraz rozbiórki i utylizacji

lośc danych i parametrow, ktore pownno się wprowadzać do projektow i brac pod uwage już na etapie koncepcji jest znacznie większa niz w projektach tradycyjnych, opracowywanych pod wieloma względami jedynie w sposob intuicyjny. Współczesne projekty architektoniczne wymagają w związku $z$ tym przeprowadzenia szeregu dokładnych analiz i symula-

\section{INTRODUCTION}

One of the components of sustainable developpes of Green Architesturn, based on the principrepared according to this concept must fulfil the requirement that while satisfying the curren needs of people they must not cause any negative

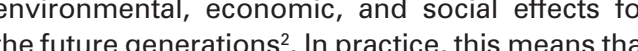
( design' must result from a multifaceted analysis of the effect of a building on man and environment the stage of its erection, utilisation, as well as (Emolition and disposal

The number of data and parameters which should be included in designs and taken into account athan in conventional designs, which in manyer spects are developed only intuitively Contemporary architectural designs require, therefore a number of precise analyses and simulations to cji, weryfikujących przyjmowane rozwiązania projektowe. To powiednich narzędzi wspomagających projektowanie w postaci oprogramowania w standardzie $\mathrm{BIM}^{4}$

Te, można powiedzieć rewolucyjne zmiany w podejściu do projektowania, stawiaja nowe wyzwania przed uczelniami zajmującymi się kształceniem przyszłych architektów. Najkróce mówiąc, konieczna jest poważna korekta programów nauczania w kierunku zinteg nego.

2. PROJEKTOWANIE ZRÓWNOWAŻONE OPARTE NA OPRAGRAMOWANIU W STANDARDZIE BIM N NA OPAGRAMOWANIU W STANDARDZIE BIM

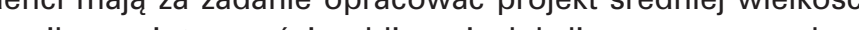
pawilonu uzy zeczosci publicznej, zlokalzowanego na placu w otoczenu miejsim, ktory w zalozeniu ma być budykiem zrównoważonym, a węc zaprojektowanym zgodnie z zasadami Green Archicectures. W związku z tym dopuszczone i rekomendowane do uzywania pizez sty dopuszą narzędzia wspomagajace projektowanie $w$ postaci oprogramowania $w$ standardzie BIM. Zastosowanie tego oprogramowania umożliwia już na etapie opracowywania koncepcji budynku wprowadzenie szeregu istotnych parametrów i wykonanie wstępnych analiz slużących zrównoważonemu projektowaniu. Wyniki tych analiz pozwalają na skorygowanie przyjętych założen projektowych i ich optymalizację. Jedną z istotnych cech budynku zrownoważonego jest energooszczędność, dlatego analizy dotyczą przede wszystkim tych aspektów projektu, które mają wpływ na ostateczny poziom wydajności energetycznej'. Elementy projektowania zrównoważonego, które są rekomendowane do wprowadzenia do opracowania projektowego w systemie BIM na etapie koncepcji to lokalizacja z uwzględnieniem parametrów klimatycznych.

Lokalizacja z uwzględnieniem parametrów klimatycznych Programy wspomagające projektowanie $w$ standardzie BIM umo liwia wprowadzenie doktad lokalizaji i umożlw ja wprowadzenie dokladnej lokalizacji inwestycji dilugośc i szerokosć geograficzna oraz wysokosć nad poziomem morza). $Z$ szerokością geograficzną jest powiązana wy

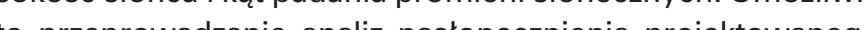
brze Aby na kolejich etapach prac projektown wybudynku. Aby na kolejnych etapoch prac projektowych wykonac analizy energetyczne projektowanego budynku niezbędne jest posiadanie odpowiednich danych klimatycznych. z Norma, czyli w przypadku zlokalizowania projektu w Krako-

z Norma, czyli w przypadku zlok
wie - dla III strefy klimatycznej.

W projektach opracowywanych przez studentów w ramac ćwiczeń projektowych już na wstępnym etapie projektu koncepcyjnego wymagane jest wprowadzenie konkretnej lokalzacji projektowanego budynku ze scisle określonymi parametrami klimatycznymi, a więc:

- temperatura powietrza

- względna wilgotnośc

- nasłonecznienie

- prędkośc i kierunek dominujących wiatrow be performed in order to verify the assumed design solutions. This in turn calls for the application of approprate design aiding tools in the designing process - software in the BlM standard.

These changes in approaching the designing prory, pose new challenges before universities and colleges that train future architects. In brief, a serious correction of the curriculum towards integrated sustainable design is necessary.

2. SUSTAINABLE DESIGN BASED ON BIM OFTWARE

At the first year of studies at the Faculty of Archidents face the task of developing a design of a medium size public utility pavilion located in a square in an urban environment, which is to be a sustainable building, and therefore designed in compliance with the principles of Green Architecture ${ }^{5}$. For this reason students are allowed and recommended to make use of design aiding tools in the form of to introduce a Application of this solware enables to perform preliminary analyses for the purposes of sustainable design already at the stage of the development of the very concept of a building. Results of such analyses allow to correct the initially adopted design assumptions and to optimise them. One of essential properties of a sustainable building is its energy efriciency, therefore, the analysis focuses fredominantly on aspects of a building which inments of sustainable design recommended to be implemented in the design study in the BIM system at the stage of the concept are the location of the building, taking into account its climatic parameters

Location taking into account climatic parameters Design aiding tools in the BIM standard enable to enter a precise location of the investment (longrameters that and connected with latitude are the solar altitude and the incidence angle of sunrays. This allows to perform analysis of insolation of the designed building. It is necessary to hold appropriate climatic data in order to perform energy-related analysis of the designed building at subsequent stages of the designing works. The external temperatures taken into account during the designing dard, so if a project is located in Cracow - they are appropriate for the $3^{\text {rd }}$ climatic zone. In designs prepared by students within the scheme of their practical design classes it is required to enter a specific location of the designed building along with closely determined climatic parameters already at the in Arage. These parameters include:

- Air temperature

- Relative humic

- Speed and direction of prevailing winds

A factor which has a significant effect on the energ characteristics of a building is the wind effect leve hat is the speed and direction of prevalling winds 
Znaczący wpływ na charakterystykę energetyczną budynku ma poziom oddzialywania wiatru, czyli preedkosc i kierunek dominujących wiatrów dla danej lokalizacji. Konkretna lokalizacja projektu i charakterystyczne dla niej oddziaływanie wiatru powinna być wytyczną do zaplanowania odpowiedniego osłoniecia lub "otwarcia” dla poszczególnych elewacji budynku.

Projektowane osłonięcia od wiatru mają wpływ na stopień tzw. zacieniania poziomego, czyli zakresu, w jakim cienie rzucane są przez obiekty zewnętrzne na elementy nieprzezroczyste budynku. Źródła zacienienia poziomego budynku wynikają z ujajujach su w okczenia budynu oraz z konstrukcii by ty same ły samego budynku. Ocenę stopnia zacienienia budynku lub jego najbiższego oczicio dwóch por roku. zimowej i letniej. zimowe zacienienie ścian i okien ukiernich energii slonecznej, natomiast zacienienie w lecie, zwłaszcza od strony zachodniej, moze okazac się korzystne, gdyż zapobiega przegrzewaniu budynku. Jeżeli istnieje taka potrzeba, otoczenie obiektu powinno byc odpowiednio modyfikowane w celu zwiększenia zacienienia lub zwiększenia dostępności promieniowania słonecznego.

Zgodnie $z$ wymogami ustawowymi pomieszczenia w budynkach powinny mieć zapewniony odpowiedni czas nasłonecznienia, określany w dniach równonocy $(21$ marca i 21 września) $)^{8}$. Zweryfikować to można tzw. analizą nasłonecznienia budynku, która pozwala na zaobserwowanie projektowanego budynku w realnej sytuacji w celu sprawdzenia warunków nasłonecznienia w określonym miejscu (położeniu geograficznym) oraz w określonym przedziale czasu

Wariantowe analizy nasłonecznienia dla projektów studenckich wykonywane są w programie Archicad z uwzględnieniem parametrów geograficznego położenia modelu i związanej z tym pozycji słońca. Dzień przeprowadzenia analizy nasłonecznienia wyznaczany jest na 21 marca. Odstępy czasowe pomiędzy poszczególnymi klatkami analizy przyjmowane są standardowo co 1 godzinę.

\section{Przeszklenia w budynku}

Ze względu na wymagany przepisami poziom oszczędzania energii już na etapie koncepcji określone powinny być również minimalne i maksymalne dopuszczalne powierzchnie okien. Proporcje wielkości przeszkleń w budynku określa Rozporządzenie w sprawie warunków technicznych ${ }^{10}$ :

- Minimalna dopuszczalna powierzchnia przeszkleń - W pomieszczeniu przeznaczonym na pobyt ludzi stosunek powierzchni okien, liczonej w świetle ościeżnic, do powierzchni podłogi powinien wynosić co najmniej 1:8

Maksymalna dopuszczalna powierzchnia przeszkleń W budynku użyteczności publicznej pole powierzchni $A_{0}$ wyrażone $\mathrm{w} \mathrm{m}^{2}$, okien oraz przegród szklanych i przezroczystych o współczynniku przenikania ciepła nie mniejszym niż $0,9 \mathrm{~W} /\left(\mathrm{m}^{2} \mathrm{~K}\right)$, obliczone według ich wymiarów modularnych, nie może być większe niz wartość $A_{\text {omax }}$ obliczone według wzoru: $A_{0 \max }=0,15 A_{2}+0,03 A_{w}$, gdzie: $A_{2}$ - jest suma pól powierzchni rzutu poziomego wszystkich kondygnacji nadziemnych (w zewnętrznym obrysie budynku) w pasie a specific location. A specific location of a project and the wind effect characteristic for it should constitute a guideline for planning a relevant shield or "openings" for individual elevations of the building Designed wind shields have their effect on the is a range in which shadows are cast by exterhal structures onto non-transparent elements of the building. Sources of horizontal shadowing of a building result from the location of the building in the area, the type and number of elements that are located in the vicinity of the building, and the structure of the very form of the building The evaluation of the degree of shadowing of the be considered for two seasons: winter and summer. Shadowing of walls and windows facing the south renders it impossible to make use of the solar energy, and shadowing in summer, especially from the western side, may turn out to be beneficial, as it prevents overheating of the building. If if is necessary, the surrounding area of the building shad be appropriately modified so as to increas Under relevant statutory provisions, rooms in buildings should have a secured period of insolation, determined on the days of the equinox $(2$ March and 21 September) $)^{8}$. It can be verified by means of the so-called building insolation analy sis, which enables to observe a specific building in a real situation in order to verify the insolation conditions in a specific place (geographical loca-

students' designs are performed in Archicad, taking into account geographical parameters of the location of the model and the position of the sun connected with it. The date set for the insolation analysis 21 March. The time intervals between individu frames of the analysis are normally one-hour long.

\section{Glass in the building}

Due to the level of energy efficiency imposed in mum admissible surface areas of windows should be determined already at the stage of the concept as well. Proportions in the size of glass surfaces in a building are specified in the Regulation on Techical Conditions ${ }^{10}:$

Minimum admissible surface area of glass - In a room intended for people's stay, the ratio of
the surface area of windows calculated in the men of the window frames to the surface area of the floor should be at least 1:8

Maximum admissible surface area of glass - In a public utility building the area $A_{0}$, expressed in square metres, of windows and glass partition with the heat transfer coefficient not lower than $0.9 W / m 2 K)$, calculated according to their moduof $A_{0}$ calculated according to the formula $\mathrm{A}_{0 \text { max }}=0,15 \mathrm{~A}_{2}+0,03 \mathrm{~A}_{w^{\prime}}$ where: $\mathrm{A}_{-}$- is a sum of areas of the floor plans of all overground floor (within the external contour of the building) in a 5 -metre-wide belt along the external walls,
$A_{w}$ - is a sum of areas of the remaining part of o szerokosci $5 \mathrm{~m}$ wzdłuz ścian zewnętrznych, $A_{w}$ - jest sumą poll powierzchni pozostalej cześci rzutu poziomego wszystkich kondygnacji po odjęciu $A$

Nie ma odrębnych zaleceń, dotyczących rekomendowane wielkości przeszkleń dla budynków niskoenergetycznyc (NF 40) i pasywnych (NF 15), która powinna być zweryfikowana przez analizy zysków i strat energii dla całego budynku' Jednak projektujac budynek energooszczedny należy miec na uwadze że okna wr naża ro zo poniewaz wprowa wudynku poprzez okna jest najprostsza forma biernego pobyskiwania energi z promis prow y, ze jedynie okna usytuowane od strony poludniowej oraz

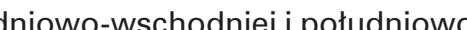
pozytywny bilans energetyczny ${ }^{12}$. Stąd w budynkach energooszczędnych zalecana jest koncentracja okien od strony południowej. Jednocześnie południowe okna powinny posiadac elementy ocieniajacce, ktore pozwaja na ochronę wnętrza przed przegrzewaniem się w okresie letnim. Z kolei na elewacji północnej zalecane jest unikanie okien, a na elewaci wschodniej i zachodniej ograniczenie ich ilości

Ponadto w projekcie koncepcyjnym należy zwrócić uwage na fakt, że w szerokościach geograficznych w jakich położona jest Polska, ilosc promieniowania słonecznego w sezoni grzewczym jest relatywnie niewielka w porównaniu do ilości promieniowania słonecznego, ktore oddziałuje na budyne w miesiącach ciepłych. W budynkach energooszczędnyc o dużej powierzchni okien od strony południowej może więc wystąpić problem przegrzewania wnętrz. W celu zachowani komfortu cieplnego $w$ okresie letnim zalecane jest w związku z tym stosowanie urządzeń przeciwsłonecznych.

\section{Instalacje i techniczne wyposażenie budynku}

$\mathrm{Na}$ etapie koncepcji projektowej, która dotyczy budynku energooszca wstepne zalazenia dotyczace rozwiazań instalacyinych i technicznego wyposażenia budynku. Dotyczą one następujących grup instalacji urządzeń:

Instalacje zapewniające wymiane powietrza i komfort cieplny - W budynkach projektowanych w sposób tradycyiny wymiana powietrza zapewniana jest przez system naturalnej wentylacji grawitacyjnej. W budynkach energooszczędnych nie da się osiągnąć wymaganego - znacznie wyższego poziomu wydainości energetycznej aniżel w standardowych budynkach normatywnych - bez zastosowania mechanicznej wentylacji nawiewno-wywiewne z odzyskiem ciepta (rekuperacja). Efektywnymi urzadzeniami w zakresie dostarczania energii cieplnej do ogrzewania budynków energooszczędnych są pompy ciepła. Zalecane uzupetnien ergooszczędnych są pompy ciepla. Zalecane kach nik ciepła (GWC).

- Instalacja ciepłej wody użytkowej - W budynkach tradycyjnych głównym składnikiem bilansu energetycznego jest zapotrzebowanie na ciepło do ogrzewania budynku, natomiast energia potrzebna do przygotowywania cie- the floor plan of all the floors after subtracting $\mathrm{A}_{2}$ There are no separate provisions as to the recommended size of glazed surfaces for low-energy buildings (NF 40) and passive buildings (NF 15) of energy gains and losses for the entire building". Nevertheless, when designing an energy efficient building it should be borne in mind that windows play an important role in low energy buildings, because introducing daylight in the building throug windows constitutes the simplest method of passive energy gain from solar radiation. Research carried out in Passivhouse Institute in Darmstad has demonstrated that only windows facing the have a positive energy balance ${ }^{2}$. Hence it is recommended to concentrate windows on the southern side of buildings. Simultaneously, windows facing the south should be furnished with shadowing elements, which allow to protect interiors against overheating in summer. On the northern elevation on the other hand, it is recommended to avoid windows, and on the eastern and west to

Furthermore, at the stage of the conceptual design it is necessary to take into account that in latitudes similar to those of Poland the quantities of solar radiation in the heating period are relatively minor compared to the quantity of solar radiation that has its effect on a building in warm months. Therefore, there may occur a phenomenon of overheating window areas facing the south. So as to mainta the heat comfort in the summertime, it is, therefore, recommended to apply sun protections.

Installations and technical fittings of the building At the stage of a design concept which refers to a energy efficient building students should define the nitial assumptions referring to installation solution and technical fittings of the building. They refer - Installations providing air exchange and he comfort - in conventionally designed buildings air exchange is provided by the system of natura gravity ventilation. In energy efficient buildings it is impossible to obtain the required - much higher - level of energy efficiency than in standard normative buildings without the application of mechanical supply-exhaust ventilation with plying heat energy for heating energy efficient buildings are heat pumps. The recommended completion of the ventilation and heating system in energy efficient buildings is the so-called ground-coupled heat exchanger.

Domestic hot water installation - In conventional buildings the main component of the energy balance is the demand for heat for heating of the tain domestic hot water constitutes only its small part. In energy efficient buildings the proportions are reversed; therefore, it is necessary to aim a the maximum reduction of heat losses in the domestic hot water installation, the decrease of the demand for hot water, and the use of renewable 
płej wody użytkowej (c.w.u.) stanowi tylko jego niewielką część. W budynkach energooszczędnych proporcje te są odwrotne i w związku z tym należy dążyć do maksymalnego ograniczenia strat ciepła w instalacji c.w.u., zmniejszenia zapotrzebowania na ciepłą wodę i wykorzystywania do jej przygotowania
słoneczne).

- Instalacje elektryczne - W budynkach energooszczednych należy zapewnić dużą efektywność wykorzystania energi (n) elektrycznej oraz w maksymalnym stopniu wykorzystywać Auziem dziennym. ligentny buynek go go technicznie budynku, keory posiada system czujników i detektón orz jeden, zinegrowany system zarządzania wszystkini znajduacymi sie w hin instalacjami. Zastosowanie w budynku automatyk powiązanej z systemem inteligentnego budynku pozwala na znaczne obniżenie zużycia energii - koszt instalacji urządzeń inteligentnego budynku to około $1-2 \%$ kosztu jego budowy, ale urządzenia te maja wpływ na obniżenie $75 \%$ kosztów eksploatacji budynku.

\section{Wykorzystanie energii ze źródeł odnawialnych}

Pasywne systemy słoneczne - Zmniejszenie zużycia energii do ogrzewania pomieszczeń można osiągnąć dzięki stosowaniu pasywnych systemów słonecznych. Systemy takie tworzą elementy budynków, które odpowiednio zaprojektowane w bierny sposób pochłaniają promieniowanie słoneczne, przepuszczają je lub magazynuja

- Aktywne systemy słoneczne - Aktywne systemy słoneczne to systemy, w których dzięki zastosowaniu specjalnych urządzeń instalacyjnych zachodzi przemiana energii promieniowania słonecznego na ciepło użytkowe. Przykładem takich urządzeń są np. kolektory słoneczne.

- Konwersja promieniowania słonecznego w energię elek-

tryczna, czyli np. ogniwa fotowoltaiczne

- Pompy ciepła, czyli urządzenia, które podbieraja energię ze źródła o niskiej temperaturze (źródło dobre i przenge ją do źródła o wyższej temperaturze (źródło górne), gdzie zostaje wykorzystana do ogrzewania pomieszczeń lub podgrzewania ciepłej wody użytkowej.

Inne źródła energii odnawialnej, takie jak biomasa, energia wiatru, itp.

Projekt wykonywany w drugim semestrze 1 roku Architektury w Instytucie Projektowania Urbanistycznego Wydziału Architektury Politechniki Krakowskiej jest kończony na etapie koncepcji funkcjonalno-architektonicznej. Uwzględnienie wymienionych elementów projektowania zrównoważonego na etapie projektu koncepcyjnego umożliwia kontynuowanie opracowania projektowego $\mathrm{w}$ fazie projektu budowlanego i wykonawczego bez istotnych korekt związanych z orientacja budynku, doświetleniem, funkcją, itp. Dzięki tak prowadzonemu nauczaniu na etapie koncepcji na dalszych etapach można uszczegóławiać decyzje projektowe. Po przypisaniu wszystkim materiałom budowlanym zastosowanym w poszczególnych elementach budynku ich cech fizycznych, można prze- tors) Electric installations - In energy efficient buildings it is necessary to secure high efficiency of mum of ectic energy and to make maxto rooms.

Automatic control and smart building systems
- smart building is a term that describes a technically highly advanced building, equipped with a system of sensors and detectors, and one integrated system of management of all the installations located in it. The application of automatic control connected with the system of a smart tion considerably - the cost of installation of smart building devices constitutes ca. 1-2\% of its construction, but these devices have their effect on the reduction of $75 \%$ of the building utilisation costs.

\section{Use of energy from renewable sources}

- Passive solar systems - The reduction of energy obtained thanks to the application of passive solar systems. Such systems are created by elements of buildings which - if properly designed - passively absorb solar radiation, transmit, or store it.

Active solar systems - Active solar systems are systems in which thanks to the application of radiation is transformed into domestic heat. Examples of such devices are solar collectors.

Conversion of solar radiation into electric en ergy, e.g. photovoltaic cells.

Heat pumps, that is devices which take energy from a low temperature source (lower source) and transport it to a higher temperature source (upper source), where it is used for heating Other rer hab do mass, wind energy, etc.

The design prepared during the $2^{\text {nd }}$ semester of the $1^{\text {st }}$ year of Architecture in the Institute of Urban Design, Faculty of Architecture, Cracow University of Technology, is completed at the stage of the functional and architectural concept. Taking into account the aforementioned elconceptual design allows to continue the design development at the stage of the building permit design and the detailed design, without any essential corrections pertaining to the building orientation, illumination increase, function, etc. Thanks to this method of teaching at the stage of the concept, design decisions can be elaborated more detail during subsequent stages of the rials applied in individual elements of the building with their physical properties, students can move on to subsequent analyses, such as the analysis of gains and losses of the final energy for the heating purposes, the analysis of comfort and overheating, etc. prowadzac kolejne analizy takie jak: analiza zyskow i strat energii koncowej na ogrzewanie budynku, analiza komfortu i przegrzewania, itp.

Poniżej przedstawiono projekty studentów I roku wykonane w oparciu o narzędzia BIM. Autorkii projektów: Dominika Poluk, Magdalena Ryś, Patrycja Seruga, Monika Sokołowska Julia Sierpień

\section{PODSUMOWANIE}

Projektowanie urbanistyczno- architektoniczne oraz budowlane wpisujące siẹ w idee zrównoważonego rozwoju wymaga koordynacji na wszystkich etapach oraz integracji działan wszystkich uczestników procesu projektowego. Projektowanie zrównoważone opiera się na określonych zasadach które sa ze sobą logicznie powiązane. Przeprowadzenie stosownych analiz oraz wprowadzenie do projektu rozwiązań określanych jako „zrównoważone”, poszerza niewątpliwie zakres opracowania, zwiększa też ryzyko popełnienia błędu. Wydaje się, że na dzień dzisiejszy, najsprawniejszym narzędziem wspomagającym projektowanie zrównoważone jes oprogramowanie BIM. Wynika to z możliwości wprowadze nia do projektu szeregu parametrów, takich jak np. położenie geograficzne i związane z nim dane klimatyczne, pozycja słońca, itp. oraz przeprowadzenia powiązanych z nimi analiz, takich jak np. analiza nasłonecznienia budynku. Bez wspomagania w postaci odpowiedniego oprogramowania analizy takie byłyby niezwykle zmudne lub wręcz niemożliwe do przeprowadzenia. Technologie komputerowe wyszły naprzeciw zwiększonym wymogom stawianym projektom i ich twórcom w dobie rozwoju zrównoważonego. Nauczanie projektowania zrównoważonego w oparciu o te technologie jest dziś niezwykle pomocne dla architektów i inżynierów, a w przyszłośc może się stać nieodzowne. Dlatego edukacja w tym zakresie oraz integracja projektowania urbanistyczno- architektonicznego oraz budowlanego wydaje się być konieczna już od pierwszych lat studiów.

PRZYPISY

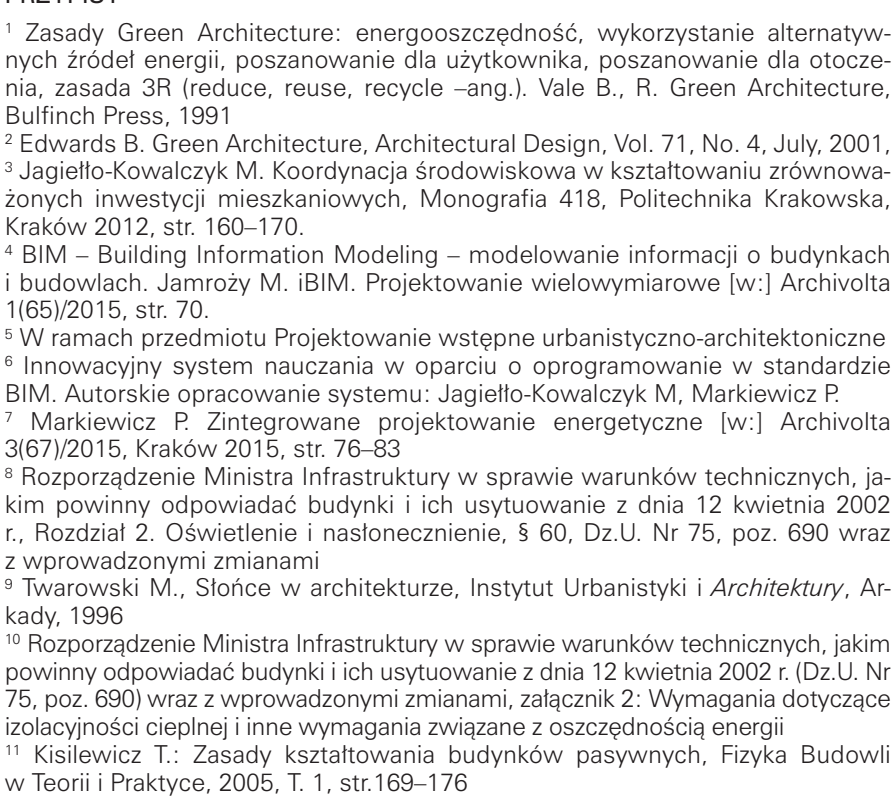

Designs by first-year students, developed using BIM tools, have been presented below: Dominika Poluk, Magdalena Ryś, Patrycja Seruga, Monika Sokołowska, Julia Sierpień.

\section{SUMMARY}

Urban / architectural and construction design in scribed in the concept of sustainable developmen gration of activities of all actors taking part in the designing process. Sustainable design is based on specific logically interrelated principles. Undoubtedly, performing relevant analyses and introducing specific solutions referred to as sustainable in the design broadens the scope of the study, and it increases the risk of an error, too. It seems tha as of today, the most efficient tool that aids the ware It results from the possibility of introc soctnumber of parameters in the design, such as e. geographical location and the climatic data connected with it, the position of the sun, etc., and the performance of analysis relating to them, such as e.g. the analysis of the building insolation. Without the help of relevant software, such analyses would be extremely laborious, or downright impossible to conduct. Computer technologies have satisfied by designs and their authors in the era of sustainable development. Teaching sustainable design on the basis of those technologies is extremely helpful for architects and engineers today, and it may become indispensable in the future. Therefore, education in this scope and integration of urban / architectural and construction designs of studies.

\section{ENDNOTES}

Green Architecture principles: energy efficiency, use of al-
ternative energy sources, respect for user, respect for the
surroundings, the rule of 3 Bs (reduce, reuse, recycle). Vale ternative energy sources, respect for user, respect for the
surroundings, the rule of 3 Rs (reduce, reuse, recycle). Vale
B., R. Green Architecture, Bulfinch Press, 1991 2Edwards B. Green A
71, No. 4, July, 2001, w ksztattowaniu zrównowazionych inwestycii miesskanio-
wych, Monograph 418, Cracow University of Technology Cracow 2012, pp. 160-170.
4 BIM - B Building Information Modelling. Jamroży M. iBIM
Projektowanie wielowymiarowe [in:] Archivolta $1(65) / 2015$. p. 70. .
5 Within the scheme of the subject Preliminary Urban / A chitectural Design.
6 Innovative teaching system based on BIM programming System development: Jagieftlo-Kowalczyk M, Markiewicz P.
7 Markiewicz P. Zintegrowane projektowanie energetyczn [in:] Archivolta 367//2015, Cracow 2015, pp. 76-83
Regulation of the Minister of Infrastructure on Technica Conditions to Be Satisfied by Buildings and Their Location
dated 12 April 2002, Chapter 2. Illumination and Insolation, $\$$ 60 Official Journal No. 75, item 690 as amended.
Twarowski M. Stonce, w architekturze, Institute of Urbat Planning and Architecture, Arkady, 1996 Regulation of the Minister of Infrastructure on Technic
Conditions to Be Satisfied by Buiddings and Their Location Conditions to Be Satisfied by Buildings and Their Location
dated 12 April 20202 (Official Journal No. 55 , item 6990 as
amended, Appendix 2: Requirements on thermal insulation

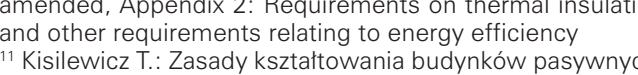

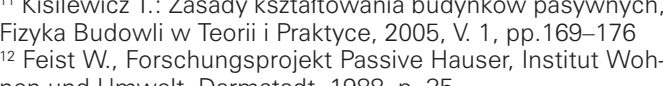


12 Feist W., Forschungsprojekt Passive Hauser, Institut Wohnen und Umwelt, Darmstadt, 1988, str.35

${ }^{13}$ Markiewicz P. Wpływ orientacji budynku względem stron świata, wielkości przeszkleń oraz konstrukcji okien i sposobu ich montażu na zużycie energii końcowej na ogrzewanie w budynkach energooszczednych [w:] Housing Environment 16/2016, Wydawnicwo Katedry Kształtowania Środowiska Mieszkaniowego, Wydział Architektury Politechniki Krakowskiej, Kraków 2016, str. 23-33.

\section{LITERATURA}

[1] Rozporządzenie Ministra Infrastruktury w sprawie warunków technicznych, jakim powinny odpowiadać budynki i ich usytuowanie z dnia 12 kwietnia 2002 r., Rozdział 2. Oświetlenie i nasłonecznienie, § 60, Dz.U. Nr 75, poz. 690 wraz z wprowadzonymi zmianami

[2] Twarowski M., Słońce w architekturze, Instytut Urbanistyki i Architektury, Arkady, 1996

[3] Rozporządzenie Ministra Infrastruktury w sprawie warunków technicznych, jakim powinny odpowiadać budynki i ich usytuowanie z dnia 12 kwietnia 2002 r. (Dz.U. Nr 75, poz. 690) wraz z wprowadzonymi zmianami, załącznik 2: Wymagania dotyczące izolacyjności cieplnej i inne wymagania związane z oszczędnościa energii

[4] Kisilewicz T., Zasady kształtowania budynków pasywnych, Fizyka Budowli w Teorii i Praktyce, 2005, T.1

[5] Feist W., Forschungsprojekt Passive Hauser, Institut Wohnen und Umwelt, Darmstadt, 1988 ,

[6] Markiewicz P., Wpływ orientacji budynku względem stron świata, wielkości przeszkleń oraz konstrukcji okien i sposobu ich montażu na zużycie energii końcowej na ogrzewanie w budynkach energooszczędnych, Housing Environment 16/2016. Wydawnictwo Katedry Kształtowania Środowiska Mieszkaniowego, Wydział Architektury Politechniki Krakowskiej, Kraków 2016

[7] Markiewicz P., Zintegrowane projektowanie energetyczne, Archivolta 3(67)/2015, Kraków 2015

[8] Jagiełło-Kowalczyk M., Koordynacja środowiskowa w kształtowaniu zrównoważonych inwestycji mieszkaniowych, Monografia 418, Politechnika Krakowska, Kraków 2012

[9] Vale B. R., Green Architecture, Bulfinch Press, 1991

[10] Edwards B., Green Architecture, Architectural Design, Vol. 71, No. 4, July, 2001
13 Markiewicz P. Wpływ orientacji budynku względem stron świata, wielkości przeszkleń oraz konstrukcji okien i sposobu ich montażu na zużycie energii końcowej na ogrzewanie w budynkach energooszczędnych [in:] Housing Environment 16/2016. Publication of the Chair of Housing Environment, Faculty of Architecture, Cracow University of Technology, Cracow 2016, pp. 23-33.

\section{BIBLIOGRAPHY}

[1] Regulation of the Minister of Infrastructure on Technical Conditions to Be Satisfied by Buildings and Their Location dated 12 April 2002, Chapter 2. Illumination and Insolation, § 60 Official Journal No. 75, item 690 as amended.

[2] Twarowski M., Słońce $w$ architekturze, Institute of Urban Planning and Architecture, Arkady, 1996

[3] Regulation of the Minister of Infrastructure on Technical Conditions to Be Satisfied by Buildings and Their Location dated 12 April 2002 (Official Journal No. 75, item 690) as amended, Appendix 2: Requirements on thermal insulation and other requirements relating to energy efficiency.

[4] Kisilewicz T., Zasady kształtowania budynków pasywnych, Fizyka Budowli w Teorii i Praktyce, 2005, V.1

[5] Feist W., Forschungsprojekt Passive Hauser, Institut Wohnen und Umwelt, Darmstadt, 1988 ,

[6] Markiewicz P., Wpływ orientacji budynku wzgledem stron świata, wielkości przeszkleń oraz konstrukcji okien i sposobu ich montażu na zużycie energii końcowej na ogrzewanie w budynkach energooszczędnych, Housing Environment 16/2016, Publication of the Chair of Housing Environment, Faculty of Architecture, Cracow University of Technology, Cracow 2016

[7] Markiewicz P., Zintegrowane projektowanie energetyczne, Archivolta 3(67)/2015, Cracow 2015

[8] Jagiełło-Kowalczyk M., Koordynacja środowiskowa w kształtowaniu zrównoważonych inwestycji mieszkaniowych, Monograph 418, Cracow University of Technology, Cracow 2012

[9] Vale B. R., Green Architecture, Bulfinch Press, 1991

[10] Edwards B., Green Architecture, Architectural Design, Vol. 71, No. 4, July, 2001, 
PROJEKT PAWILONU USŁUGOWO-WYSTAWIENNICZEGO

NA PLACU PO GIGANCIE
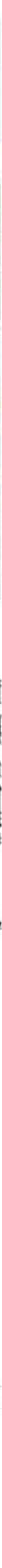

Totson

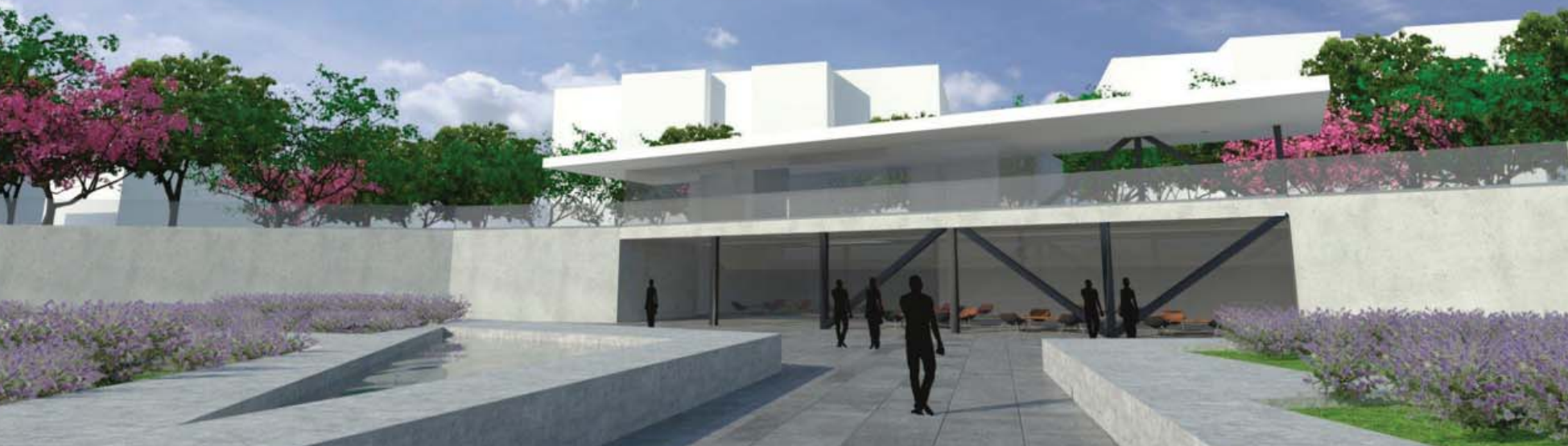


PROJEKT PAWILONU USŁUGOWO - HANDLOWEGO
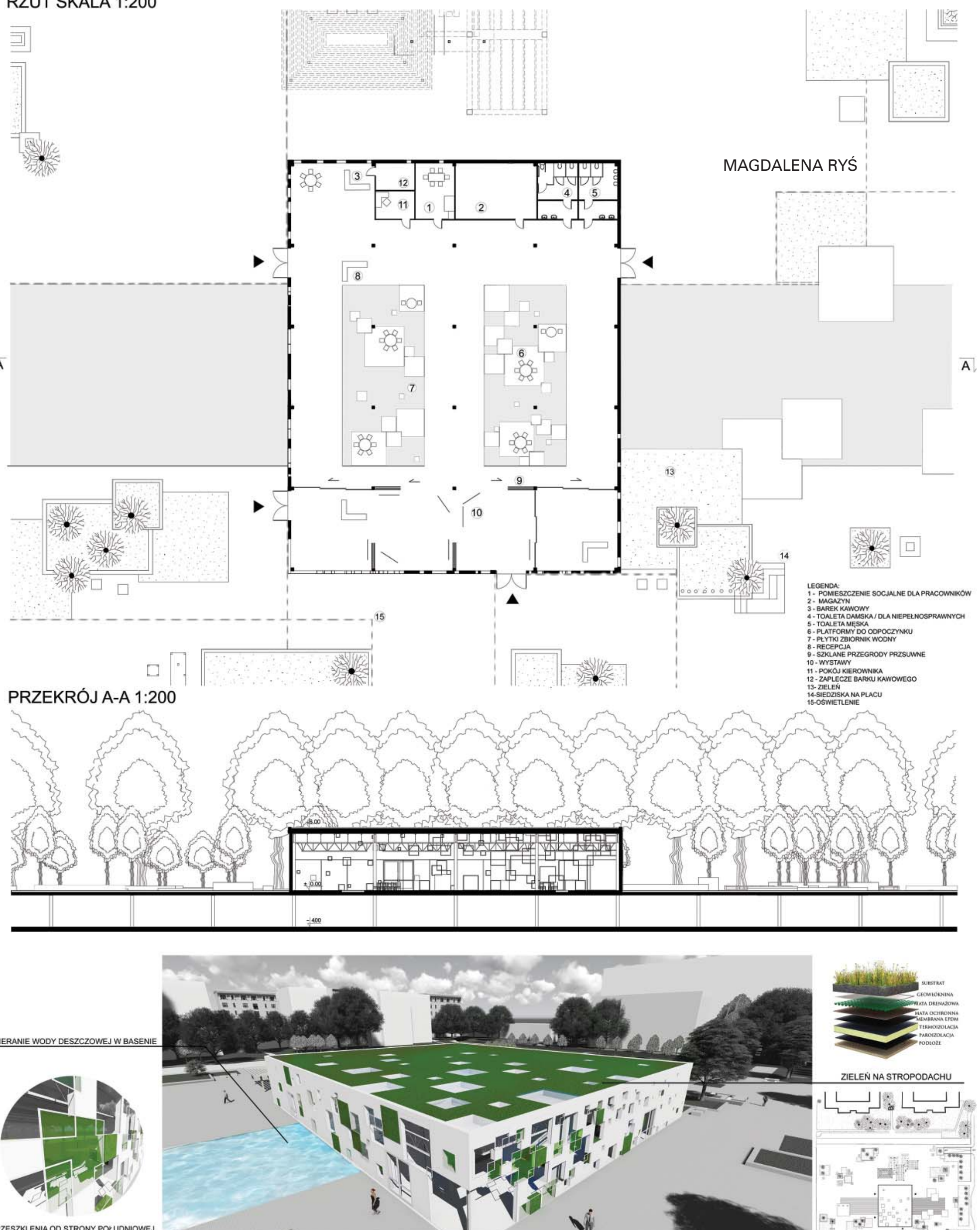

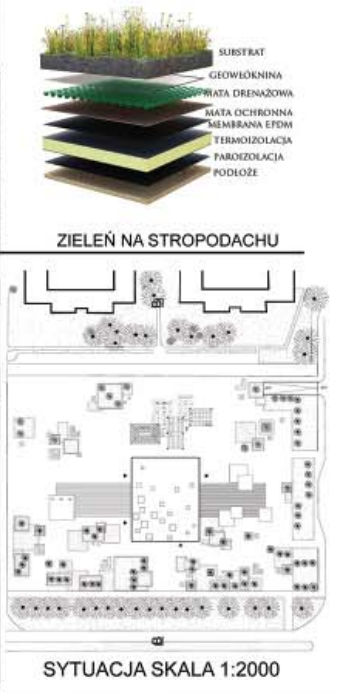

PAWILON WYSTAWOWY W ANDRYCHOV
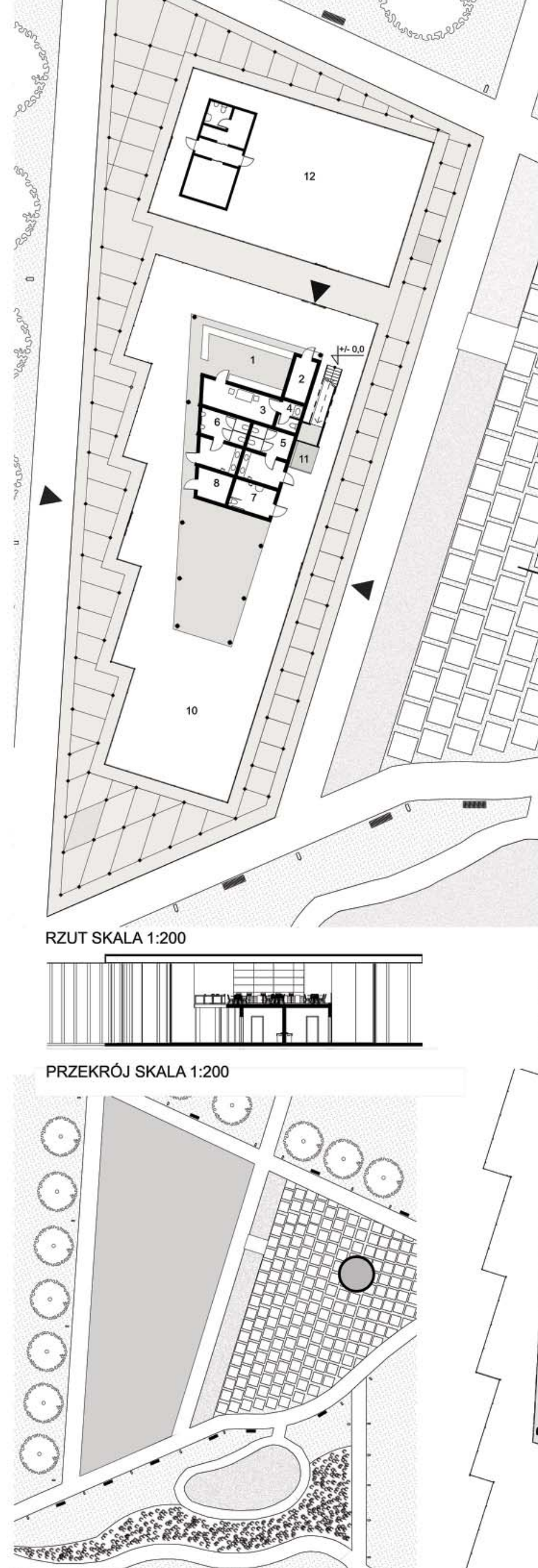

RZUT SKALA 1:500

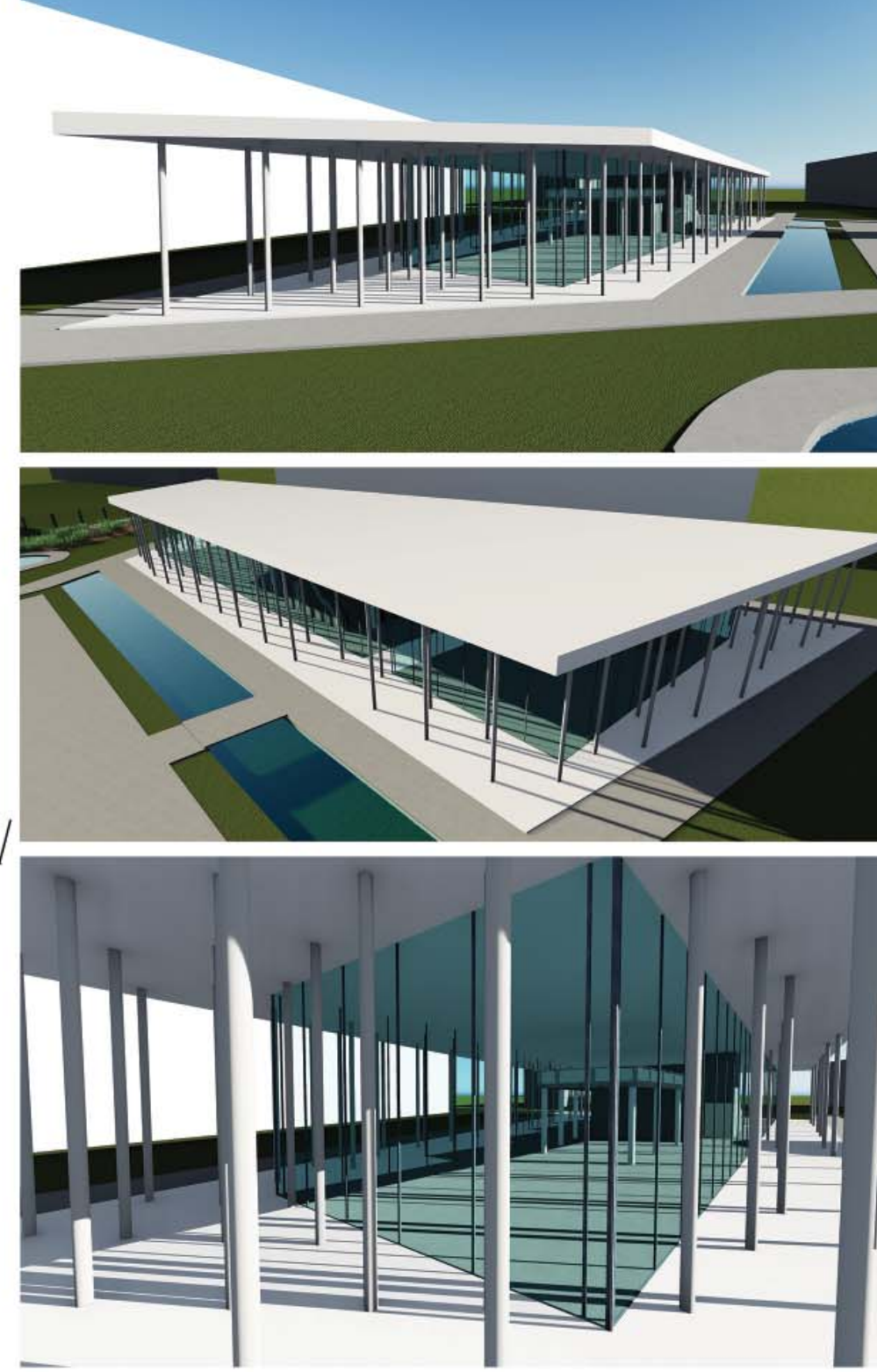

EGENDA: PATRYCJA SERUGA

8- ZAPLECZE

10. PRZESTRZEN WYSTAWOWA 11- WINDADLANIEPEENO
12 - CZESSC USEUGOWA

(1) WC DAMSK

EPEENOSPRAWNYCH

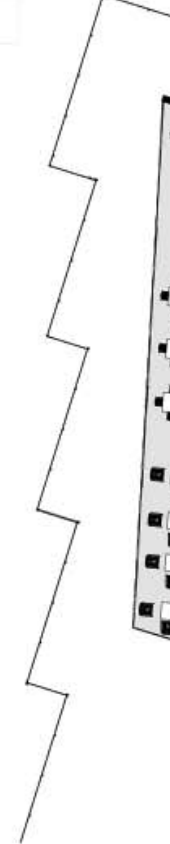

ODZYSK WODY DESZCZO<smiles>C#C[C@H]1CC[C@H]1C#C</smiles>

OCZYSZCZALNIA TRZCINO

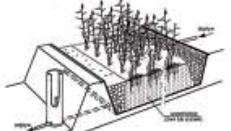

ENERGOOSZCZĘDNOŚĆ

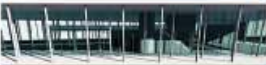

LEGENDA:

32DD-PRZESTRZEN

T:- OCZYSZCZA

- OSWIETLENIE - PAWLON
WYSTAWOWY 


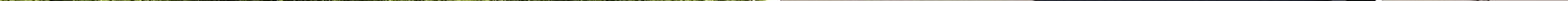

